Marquette University

e-Publications@Marquette

English Faculty Research and Publications

English, Department of

$12-1-2016$

Being Together Subversively, Outside in the University of Hegemonic Affirmation and Repressive Violence, as Things Heat Up (Again)

Jodi Melamed

Marquette University, jodi.melamed@marquette.edu

Accepted version. American Quarterly, Vol. 68, No. 4 (December 2016): 981-991. DOI. (C) 2016 Johns Hopkins University Press. Used with permission. 


\title{
Being Together Subversively, Outside in the University of Hegemonic Affirmation and Repressive Violence, as Things Heat Up (Again)
}

\author{
Jodi Melamed \\ Department of English, Marquette University \\ Milwaukee, WI
}

\begin{abstract}
The Imperial University: Academic Repression and Scholarly Dissent. Edited by Piya Chatterjee and Sunaina Maira. Minneapolis: University of Minnesota Press, 2014. 400pages. \$23.98 (paper).

The Reorder of Things: The University and Its Pedagogies of Minority Difference. By Roderick A. Ferguson. Minneapolis: University of Minnesota Press, 2012. 286pages. $\$ 25.00$ (paper).

The Undercommons: Fugitive Planning and Black Study. By Stefano Harney and Fred Moten. New York: Autonomedia, 2013. 166pages. \$21.49 (paper).
\end{abstract}

"Who the fuck made you master?" This is Tavia Nyong'o's paraphrase of the spirit of the demands of the new freedom struggles on campus. 1 They can be described as black, undocumented, black feminist, queer of color, decolonial, anti-austerity, pro-Palestine, robustly intersectional, and, at times, abolitionist. They have also been described as reformist (rather than revolutionary), too limited by a desire for institutional recognition, and vulnerable to familiar strategies of repressive incorporation: therapeutic measures, symbolic gestures, and diversity management. In my understanding, Nyong'o's paraphrase captures a moment of repudiation: How is it that the US academy can go on with business as usual, when its conditions of possibility have been exposed as the afterlives of slavery and ongoing

[American Quarterly, Vol 68, No. 4 (m yyyy): pg. 981-991. DOI. This article is (C) [Johns Hopkins University Press] and permission has been granted for this version to appear in e-Publications@Marquette. [Johns Hopkins University Press] does not grant permission for this article to be further copied/distributed or hosted elsewhere without the express permission from [Johns Hopkins University Press].] 
settler colonialism being made anew in neoliberal debt regimes, in expanded economies of dispossession, and in routine racialized devaluation and extreme acts of racial cruelty, including police killings? As Cathy Cohen notes, the young leaders of the new student movements have "often been in our classrooms." 2 They "have been in African American studies [End Page 981] classes . . . in ethnic studies classes . . . in feminist, gender and women's studies classesthese might even be their majors." What is the relationship between these interdisciplines and the campus protests, however tenuous? How might we take up the students' repudiation as a call to investigate both the obscene resilience of what we can call the "neoliberal university of open inequality" and the capabilities of oppositional intellectual labor, which the university differentially sustains and sometimes expels.

Roderick Ferguson's Reorder of Things: The University and Its Pedagogies of Minority Difference, Stefano Harney and Fred Moten's Undercommons: Fugitive Planning and Black Study, and Piya Chatterjee and Sunaina Maira's Imperial University: Academic Repression and Scholarly Dissent are up to the task. Each provides a valuable analysis of the academic-political conjuncture we inhabit and inspires forms of practice, accountability, and collectivity within the university, behind its back, and beyond its reckoning. There are many overlaps, contrasts, and tensions between the three volumes, and these are illuminating in themselves. While a good deal of their intellectual-political genealogy is shared-The Reorder of Things and The Undercommons take up the Black Radical tradition, The Reorder of Things and The Imperial University owe much to women of color feminism-ultimately, each conceives the academy's specific mode of power somewhat differently. The concept of the political takes a different shape in each. And each text is formally quite different from the others, following from the different interventions each emerges from, aligns with, and conjures for the future. Importantly, each work never lets the reader forget that battles are raging and that this specific moment of insurgency and counterinsurgency crossing the university follows on the heels of prior (un) settlements, presenting new possibilities and dangers.

In The Reorder of Things, the scenes of battle that change everything are the student protests of the late 1960s and the 
strategies of affirmation and exclusion used by universities to manage student demands and regulate knowledge production about minority difference. Ferguson writes brilliantly about two of the most important struggles of the time: the movement to found the Lumumba-Zapata College at the University of California, San Diego, and the Open Admissions movement at the City University of New York. In his recounting, these and similar movements across the country become legible as radical deployments of minority difference, which sought to vivify the university as a radical force for epistemic and social transformations against racial, social, and class oppression. From the curriculum of study proposed for the Lumumba-Zapata college, which sought to challenge the construction of the Western rational subject, to the demand that all black and Puerto Rican [End Page 982] students be admitted to City College so that university life would be rooted in and for the community of Harlem, Ferguson demonstrates how, for the student movements, "minority difference would not be a simple matter of identity; it would become an emergency lexicon for social practice throughout the country" (52). In other words, transformation of the university was to be a means (not an end) to a radical reformation of relations between people, knowledge formations, and institutions.

The epochal shift at the heart of The Reorder of Things, however, is in the hegemonic. Specifically, it is a story of how the university's archival mode of power expands and recalibrates in order to affirm minority difference in a register that produces an adaptive hegemony (recognition, cultural affirmation, commodification, and diversity industries) while defusing the student movements' radical, redistributive demands. In Ferguson's telling, the post-1968 university comes to serve a pedagogical function for state and capital, training these in new modes of calculating with minority difference and thus expanding their capacities of governance and modes of valorization. In Ferguson's words, "What came after the challenges of the ethnic and women's movements was not the end of power but its new beginning. . . . Indeed, the cultural center was recalibrated in terms of diversification rather than standardization, no longer a center organized around a homogeneous national identity, but now a center structured according to the capacities for and principles of heterogeneous absorption. This is the historical period that tried to perfect the motto 'e pluribus unum' as a technique of power, as a 
strategic situation for the U.S. nation state, for American capital, and for the American academy" (29).

Ferguson identifies the post-1968 university as exercising a specific mode of power: "The 'academy' names that mode of institutionality and power that delivers [minority difference] over for institutional validation, certification, and legibility, bringing them into entirely new circumstances of valorization" (144). Against the tendency to see economic forces as determining the university's ethos, Ferguson demonstrates how the university, since taking on the function of producing and regulating meaning about racial difference, has taught state and capital new modes of marketing, incorporating, commodifying, governing, and (de)valorizing minority difference and minoritized subjects. The concrete examples Ferguson offers are telling. In the chapter "The Proliferation of Minority Difference," Ferguson tracks how globalizing corporate enterprises came to invest in the commodification of codes of minority difference stolen from social movements. The epitome of this might be the iconic 1971 CocaCola commercial featuring a crowd of young people differentiated by race, gender, and nationality standing together on top of a hill, singing a commercialized [End Page 983] version of a prominent peace anthem to the refrain, "I'd like to buy the world a Coke" (65). Representing and commodifying, in one fell swoop, feminist, peace, antiracist, and anticolonial movements, the commercial libidinizes the consumption of coke products as taking part in social movements, as a way to experience their buzz, purpose, and solidarity.

The Reorder of Things is centrally concerned with the contradictions of the institutionalization of black and ethnic studies in US universities and investigates these with a historical specificity and political-intellectual complexity unmatched in other scholarship. In the chapter "The Reproduction of Things Academic," Ferguson uses a reading of Toni Cade Bambara's short story "My Man Bovanne" to demonstrate how the institutionalization of black studies, rather than turning the university into a resource for black communities, profoundly reorders relations of value among members of black communities, creating new categories of "ideal" subjects (such as "the grass roots" or "nationalists"), which discipline community members inside and outside the university. In Bambara's story, Miss Hazel, the protagonist, is disciplined by her "conscious" college-age children for

[American Quarterly, Vol 68, No. 4 (m yyyy): pg. 981-991. DOI. This article is (C [Johns Hopkins University Press] and permission has been granted for this version to appear in e-Publications@Marquette. [Johns Hopkins University Press] does not grant permission for this article to be further copied/distributed or hosted elsewhere without the express permission from [Johns Hopkins University Press].] 
failing to perform her designated part as "grass roots" to their liking. In particular, she fails them by flirting with the title character, an older, deferential blind neighbor who, to the young people, represents the opposite of racial pride.

In general, The Reorder of Things profoundly engages the paradoxes and limits of institutionalization in an era of brokered affirmations, from the fact that even the most rebellious student protests evinced a desire for institutionality to the consideration of how the interdisciplines foster new conditions for both the multiplication of power and new critical deployments of race, gender, and sexuality. Ultimately, the historical arc of power's solicitations of minority difference in The Reorder of Things resolves in the present with what Ferguson calls an almost fully realized "will to institutionality" in the neoliberal university (214). According to Ferguson, with the incorporation of queer sexuality as an object of the administrative ethos of the neoliberal university, we can mark a developed form of this will to institutionality that "requires that subjects treat the administration as a matter of libido" (223). For Ferguson, this produces a situation of stultification, which treats institutionalization as "a historical necessity rather than one item on a menu of interventions" and "the standard of the evolved and developed critical subject" (226).

Yet Ferguson warns against a romantic anti-academy, antiinstitutionality position, which would mistakenly render the hegemonic as total. Rather, in the spirit of the student movements, he blends suspicion toward institutionality with a sense of the irreducible openness of all structures congealed out of social [End Page 984] forces, subject to the contested reproductions of hegemony and resistance. He takes inspiration from June Jordan's description of black studies as "life studies," "a field meant to dream horizons that exceed prescriptions and violences of institutional excellence," which "turns to minoritized communities as forces of negation that compel the imagination to exceed the given state of affairs" (109). The Reorder of Things ends with a call to activate the revolutionary potential of "little acts of production" (writing a syllabus, making an olive oil balm for a neglected elder) to incite and protect a dynamism around the meanings of minority culture, a dynamism that diminishes hegemony's

[American Quarterly, Vol 68, No. 4 (m yyyy): pg. 981-991. DOI. This article is @ [Johns Hopkins University Press] and permission has been granted for this version to appear in e-Publications@Marquette. [Johns Hopkins University Press] does not grant permission for this article to be further copied/distributed or hosted elsewhere without the express permission from [Johns Hopkins University Press].] 
reorder of things through calcified deployments of minority difference (232).

In counterpoint to the contemplation of past and present social movements in The Reorder of Things, in The Undercommons, Harney and Moten want to incite movements of the social. They are interested in using the text to circulate relationality in the here and now to incite a creative/self-defensive disorder in the face of the antisociality of all neoliberal institutions, especially as represented by the university. The Undercommons is less scholarship than manifesto, and less manifesto than sociopoesis, a scholarly, performative, poetic making and doing of (textual) sociality in antagonism to the normalized habitus of the social. Where The Reorder of Things describes the seductions of hegemonic affirmation and thinks resistance, The Undercommons wants to seduce its readers, not just away from commitment to the hegemonic, but into its social/textual space and practice, into the community (however figurative, however existent), the fugitivity, it conjures.

In The Undercommons, the scene of battle is everywhere, and the point is not winning but escape from "the hard materiality of the unreal" sustained by structures of dominance and the battle itself (18). As I have described elsewhere, the performance of The Undercommons is structured around the play of two categories of terms:

1) terms that distill the specific violences of neo/liberal modes of institutionality, which reduce and harm human capacities of sociality and continuously refresh the coloniality and raciality of institutional forms, and 2) terms that help us think and organize desire for forms of social being that are illiberally collective, unoccupied by professionalism, sociopoetical, in-the-making, and shared, that are beyond the logics of . . . Enlightenment traditions and critical moves that fall under the category of legitimation-by-reversal (i.e., the commons as reverse legitimation of privatization, redistribution as the reverse legitimation of dispossession). ${ }^{3}$

"Politics" belongs to the first category of terms that describe the formalization, truncation, and privatization of social being through dominant institutions, which regulate (apprehension of) the conditions 
of the material and the real. [End Page 985] In Harney and Moten's work, "politics" names the assemblage of institutions, actors, and rationalities that engender remedies, fixes, governance, and policy through pathologization, by evaluating bare life as inadequate, and inviting critique, solutions, improvement, and self-improvement. Against "politics," black radicalism, for Harney and Moten, "asserts a metapolitical surrealism that sees and sees through the evidence of mass incapacity, cutting the despair it breeds" (73; emphasis added). In their own efforts to escape the violence of "politics," Harney and Moten offer the sociopoesis of the statement "there's nothing wrong with us" (20). In their words, "We're just antipolitically romantic about actually existing social life," and "We are the general antagonism to politics" (20).

"University" also belongs to the first set of terms. In fact, "university" represents neo/liberal institutionality writ large, situating this in a developing genealogy of unfreedom whose strategies include racial capitalist, settler colonial, and liberal democratic logics alike. In the chapter "The University and the Undercommons," one subheading captures this perfectly: "The university is the site of the social reproduction of conquest denial" (41). In counterpoint to Ferguson's analysis of the academy as that specific mode of power which regulates knowledge about minority difference, Moten and Harney describe the university as an exemplification of neoliberal institutionality in general, one that teaches us knowledge of how to neglect sociality. Its closest cousin is the prison, "since they are both involved, in their way, with the reduction and command of the social individual" (42).

"Undercommons" belongs to the second set of terms. Moten and Harney introduce it as a beneath and beyond of the university, yet in the interview with Stevphen Shukaitis in the book's last chapter, Harney states, "I don't see the undercommons as having any necessary relationship to the university. And given the fact that, to me, the undercommons is a kind of comportment or on-going experiment with and as the general antagonism, a kind of way of being with others, it's almost impossible that it could be matched up with particular forms of institutional life" (112). Joined with such terms as "prophetic," "organization," "study," and "the shipped," "undercommons" is a tool for thinking and celebrating "the necessarily permission has been granted for this version to appear in e-Publications@Marquette. [Johns Hopkins University Press] does not grant permission for this article to be further copied/distributed or hosted elsewhere without the express permission from [Johns Hopkins University Press].] 
failed administrative accounting of the incalculable" and "subjectivity unlawfully overcome by others" $(51,28)$. It names a being together which preserves and enacts a sociality that is ruptural, excessive, joyful and constitutes resistance to neoliberal proceduralism in and of itself. Indeed, throughout the text's performances, the concept of the undercommons holds a special weight of desire and meaning, circulating as a term for "the nonplace of abolition" and a refuge for maroons, castaways, and fugitives (42). [End Page 986]

The problem of intellectual activism within the university, which The Reorder of Things examines in terms of the seductions of affirmation that the university offers to scholars of minoritized difference, plays out in The Undercommons in the opposition between the "critical academic" and the "subversive intellectual." The critical academic is caught completely in the game of legitimation-by-reversal: "To be a critical academic in the university is to be against the university, which is to recognize it and be recognized by it" (31). Worse, as one chapter subheading states, "critical academics are the professionals par excellence" (38). For Harney and Moten, this means they are the trickiest purveyors of governance and of the diminution of shared social being: "To distance oneself professionally through critique, is this not the most active consent to privatize the social individual?" (38).

The subversive intellectual, on the other hand, is in but not of the university. Rather than oppositional, Moten and Harney describe the subversive intellectual's relationship to the university as criminal. Unrecognized, devalued, and viewed with suspicion from the viewpoint of professionalism, the subversive intellectual comes to steal from the university for what Harney and Moten call "prophetic organization," which can be thought of as a radical collective orientation toward knowledge projects. In their famous description (often taken up as referring to adjuncts or graduate students), "the subversive intellectual came [to the university] under false pretences, with bad documents, out of love. Her labor is as necessary as it is unwelcome. . . . She disappears into the underground, the downlow low-down maroon community of the university, into the undercommons of the enlightenment, where the work gets done, where the work gets subverted, where the revolution is still black, still strong" (26).

[American Quarterly, Vol 68, No. 4 (m yyyy): pg. 981-991. DOI. This article is @ [Johns Hopkins University Press] and permission has been granted for this version to appear in e-Publications@Marquette. [Johns Hopkins University Press] does not grant permission for this article to be further copied/distributed or hosted elsewhere without the express permission from [Johns Hopkins University Press].] 
It is possible, but ultimately wrongheaded I think, to read The Reorder of Things and The Undercommons as projects that provide the means to critically assess each other. It is true that The Undercommons constantly deploys minority difference (to follow Ferguson), especially in its setting to work of the language and concept of blackness. For example, in the chapter "Blackness and Governance," Harney and Moten improvise with statements such as "to discover how blackness operates as the modality of life's constant escape" and "'There's nothing wrong with blackness': What if this were the primitive axiom of a new black studies underived from the psychopolitical-pathology of populations?" $(51,47)$. Yet this is not hegemonic deployment of minority difference (and may well count as a radical one in Ferguson's framework). Moreover, both texts share an energizing sense of what a black studies aligned with impulses of the Black Radical tradition could be. It is true that The Undercommons takes risks with its way of deploying minority difference. I, for one, declined the authors' [End Page 987] invitation to think professionalization as "an encircling of war wagons around the last camp of indigenous women and children" (34). (To me, that particular deployment felt superficial and out-of-touch with indigenous critical theory.) But where the text links deeply with black radicalism or autonomism, the risk seems worth it.

Considered from the other direction, it might appear that The Reorder of Things does not indict the "critical academic" as forcefully as does The Undercommons. Indeed, there is a contrast between Ferguson's investigation of how affirmation and regulation become bound together, producing minority difference as a new site of contradiction, and Harney and Moten's incitement to think beyond "for and against," so as to be able to inhabit a "with and for," which, according to Jack Halberstam, "allows you to spend less time antagonized and antagonizing" (11). Yet ultimately, both texts are remarkable for surfacing the intellectuality of situations where people think together outside the university and beyond its ken (at barbershops and house parties, in cars and bathtubs, on picket lines), something Ferguson talks about as activating community as a spur for epistemic transformations and Harney and Moten call "study."

The Imperial University, an edited volume of essays, takes on the politics of now at universities in more familiar terms than the two 
works considered above. This is because the acts of repression, criminalization, and violence toward scholars and students that the volume reports and analyzes have been occurring around us in university quads, classrooms, faculty meetings, and dean's offices. In addition, the book's concern with "how higher education is firmly embedded in global structures of repression, militarism and neoliberalism" has become a central topic of American studies and critical university studies scholarship (3).

Piya Chatterjee and Sunaina Maira take great care to bring the battles on university campuses home to readers with great immediacy and in their full connection to warfare, militarism, racism, the politics of nationalism, and neoliberal versions of imperial violence. They begin their coauthored introduction as eyewitnesses to particular battles: Chatterjee writes from the middle of a 2012 protest against austerity measures at the University of California, Riverside, where she witnesses SWAT teams and helicopters dispersing student protestors from the "commons" and wonders about the relationship between "this militarized performance of state university power and its 'normalization' within the quiet green peace of a public university campus" (2). From Ramallah, Palestine, Maira watches the pepperspraying of students at the University of California, Davis. She observes repression and resistance unfolding across [End Page 988] one (discontinuous) field of battle, in which students in Palestine, Palestinian solidarity activists in the United States, and students demonstrating against debt and austerity measures (with these groups overlapping) find themselves criminalized for their solidarity with one another and for the acts of protest that empower them. In contrast to Ferguson's investigation of the specific mode of academic power as the regulation of knowledge about minority difference, and Harney and Moten's investigation of the asociality of neo/liberal institutionality through the example of the university, Chatterjee and Maira are interested in the university specifically as an "imperial 'knowledge complex'" (12). They seek to illuminate "the intersecting fronts of academic, cultural and military wars," in particular by examining the suppression of dissenting scholars and impermissible academic knowledge (13). As the editors note, The Imperial University uniquely analyzes Palestinian issues in the US academy in the broader context of settler colonialism and the repressive strategies of right-wing critics.

[American Quarterly, Vol 68, No. 4 (m yyyy): pg. 981-991. DOI. This article is @ [Johns Hopkins University Press] and permission has been granted for this version to appear in e-Publications@Marquette. [Johns Hopkins University Press] does not grant permission for this article to be further copied/distributed or hosted elsewhere without the express permission from [Johns Hopkins University Press].] 
What is most important about the volume is the conversation it stages among dissident university scholars. This brings into relief and relation a wide scope of topics, including the history of colonial education in imperial universities in US-controlled territories (Bascara); an examination of the CIA's use of the university for diversity recruitment (González); administrative strategies for criminalizing nonviolent protest and repressing the boycott, divest, and sanction movement (Godrej, Abowd); the survival strategies of black feminist pedagogy (Gumbs); and the pinkwashing of Israel on US campuses (Puar). In addition, The Imperial University features analysis from faculty who have been singled out and attacked for their speech and activism on issues such as US militarism in the Middle East (De Genova), on Israel/Palestine (Salaita), and for simply being hated by the right wing (Prashad). The formats of the book's chapters are heterogeneous; they include ethnic studies and gender and sexuality studies scholarship, a critical dialogue, and a one-act play by Ricardo Dominguez, which keenly dramatizes his interview with FBI agents about a virtual sit-in performance against the University of California Office of the President.

The most urgent content in The Imperial University are those passages where scholars analyze their own experiences of censorship and repression. These occur in nearly every essay. Outstanding examples include Ana Clarrisa Roja Durazo's narrative of her exile from a heteropatriarchal Chicano studies complicit with colonizing orders, Steven Salaita's description of his tenure battle at Virginia Tech in a climate using support for Israel as a litmus test for acceptable multiculturalism, and Nicholas De Genova's reflections on crossing the line of permissible speech during the buildup to the Iraq War (when, during a teach-in, he spoke of hope for "a million Mogadishus," in an [End Page 989] attempt to make audiences confront the volume of death war brings). At its best, the instances of participant analysis in The Imperial University constitute what Cherríe Moraga in This Bridge Called My Back identified as "theory in the flesh," urgent conjunctural analysis from embodied locations. ${ }^{4}$ In these instances, The Imperial University also shares with This Bridge a gathering-us-in quality, an impulse to create deeper and sustaining networks among dissident intellectuals. Although the volume does not serve as a watershed for intellectual and social movement (as This Bridge did for women of color feminism), The Imperial University recalls important projects,

[American Quarterly, Vol 68, No. 4 (m yyyy): pg. 981-991. DOI. This article is (C [Johns Hopkins University Press] and permission has been granted for this version to appear in e-Publications@Marquette. [Johns Hopkins University Press] does not grant permission for this article to be further copied/distributed or hosted elsewhere without the express permission from [Johns Hopkins University Press].] 
forums, and networks linking leftist scholars in the Cold War. In the words of its editors, it constitutes "a project of solidarity [which] aims to help support and build dissent focused on dismantling empire, and thinking freedom otherwise" (43). (But what would it mean to "dismantle empire" now? The introduction does not give its readers handles to think this.)

While The Reorder of Things investigates the dilemmas that the institutionalization of knowledge about minority difference presents to black studies scholars and other intellectual activists, and The Undercommons provides a broad theoretical meditation on the complicities of the critical intellectual and the ways of the subversive intellectual, The Imperial University examines some of the everyday contradictions faced by progressive scholars in what the editors describe as today's academic-military-prison-industrial complex. Yet, as with the other two volumes, Imperial University provides valuable moments of critical estrangement, when, in the act of reporting on university politics right now, normative elements of those politics become legible as traps and strategies of repression-as-usual.

An important example is the critical analysis of the history and present of the deployment of the concept of academic freedom, an analysis threaded throughout the editors' introduction. From its early twentieth-century emergence as a fundamentally corporate protection to its irrelevance in the era of McCarthyism, to its function now as a way to police the boundaries of permissible dissent, the editors convincingly set out a case for how "the holy grail of academic freedom ... . has been institutionalized as a limited and problematic horizon for progressive academic mobilization" (42). Another crucial example is Laura Pulido's analysis of how the successful efforts of administrators to transform the University of Southern California into an elite "world class" institution required the diminishment of faculty governance to the extent that even tenure has been naturalized as a process that administrators can delay and deny at will. Pulido illuminates the complicity of compliant faculty, as well as administrative uses of proceduralism to push out faculty of color not [End Page 990] aligned with its corporate standards. Among other noteworthy examples is Julia C. Oparah's critique of the "carceral academy": the increasing embedding of higher education in the global political economy of prisons (military, private, and state) materially, permission has been granted for this version to appear in e-Publications@Marquette. [Johns Hopkins University Press] does not grant permission for this article to be further copied/distributed or hosted elsewhere without the express permission from [Johns Hopkins University Press].] 
through corporatization, and ideologically, by disseminating tropes of criminalization and interpellating educated elites as essentially a global warden class (115).

In summary, the relevance of all three volumes is palpable. The Reorder of Things, The Undercommons, and The Imperial University each, in different but complementary ways, respond effectively to the anthems of repudiation of the new student protests, whose spirit Nyong'o paraphrases with the accusation, "Who the fuck made you master?" To my ears, this phrase signals an awareness that the battle crossing the university condenses many fronts: the fight against austerity, with the rejection of the obscene privileges of beneficiaries of financialization, with struggles for freedom from the potent afterlives of slavery, with movements to decolonize in the face of ongoing settler colonial occupations and substitutions of lifeworlds for dead profits. The Reorder of Things, The Undercommons, and The Imperial University sharpen our thinking about what it is to resist, calling on sociality itself, especially the sociality of thinking and being together, as a source of fortitude, dynamism, and replenishment.

\section{Notes}

1. Tavia Nyong'o, "The Student Demand," Bully Bloggers, November 17, 2015, bullybloggers.wordpress.com/author/afrofuturist/. Yale's residential college system employs the term master to designate the chief administrative officer, often a faculty member, for each of its twelve residential colleges. Yet clearly the term carries with it a recognition that Yale and the US university system as a whole would not exist without the wealth and labor of enslaved people and without the dispossession and enslavement of American Indians, whose education was often the alibi for the founding of colleges we know recognize as the America's most elite. See Craig Wilder, Ebony and Ivy: Race, Slavery, and the Troubled History of America's Universities (New York: Bloomsbury, 2013).

2. Cathy J. Cohen and Sarah J. Jackson, "Ask a Feminist: A Conversation with Cathy Cohen on Black Lives Matter, Feminism, and Contemporary Activism," Signs (Summer 2016), signsjournal.org/aska-feminist-cohen-jackson/.

[American Quarterly, Vol 68, No. 4 (m yyyy): pg. 981-991. DOI. This article is C [Johns Hopkins University Press] and permission has been granted for this version to appear in e-Publications@Marquette. [Johns Hopkins University Press] does not grant permission for this article to be further copied/distributed or hosted elsewhere without the express permission from [Johns Hopkins University Press].] 
NOT THE PUBLISHED VERSION; this is the author's final, peer-reviewed manuscript. The published version may be accessed by following the link in the citation at the bottom of the page.

3. Jodi Melamed, "Proceduralism, Predisposing, Poesis: Forms of Institutionality, in the Making," Lateral: Journal of the Cultural Studies Association 5.1 (2016), csalateral.org/wp/issue/5-1/forum-althumanities-institutionality-making-melamed/.

4. Gloria Anzaldúa and Cherríe Moraga, This Bridge Called My Back: Writings by Radical Women of Color (New York: Kitchen Table, Women of Color, 1983), xxiv. [End Page 991]

[American Quarterly, Vol 68, No. 4 (m yyyy): pg. 981-991. DOI. This article is @ [Johns Hopkins University Press] and permission has been granted for this version to appear in e-Publications@Marquette. [Johns Hopkins University Press] does not grant permission for this article to be further copied/distributed or hosted elsewhere without the express permission from [Johns Hopkins University Press].] 